\title{
The Distribution of Cholecystokinin-8 in the Central Nervous System of Turtles: An Immunohistochemical and Biochemical Study
}

\author{
ANTON REINER* AND MARGERY C. BEINFELD $\dagger$ \\ *Department of Anatomy and Cell Biology, University of Michigan, Ann Arbor, MI 48109 \\ and $\nmid$ Department of Pharmacology, St. Louis University, School of Medicine, St. Louis, MO 63104
}

\author{
Received 1 October 1984
}

\begin{abstract}
REINER, A. AND M. C. BEINFELD. The distribution of cholecystokinin-8 in the central nervous system of turtles: An immunohistochemical and biochemical study. BRAIN RES BULL 15(2) 167-181, 1985,-..Immunohistochemical techniques, radioimmunoassay (RIA) and high performance liquid chromatography (HPLC) were used to: (1) determine the regional distribution and amounts of cholecystokinin-8 (CCK8)-like immunoreactivity in the turtle central nervous system. and (2) chemically characterize the CCK8-like material present in the turtle central nervous system. High levels of CCK8-like immunoreactivity were found in the turtle central nervous system, with the highest levels being present in the hypothalamus and neurohypophysis. Moderate levels of the CCK8-like material were found in all other regions of the turtle nervous system except the cerebellum, the olfactory bulbs and the dorsal ventricular ridge of the telencephalon, which contained low levels. The bulk (87\%) of the CCK8-like material in turtle central nervous system co-eluted with CCK8-sulfate in gradient elution HPLC. The distribution of CCK8-like immunoreactivity (CCK8LI) observed using immunohistochemistry was consistent with the results of the RIA studies. Numerous CCK8LI-containing neurons and fibers were observed in the hypothalamus and neurohypophysis. Neurons and fibers containing CCK8 were, however, more sparsely distributed outside the hypothalamus. The immunohistochemical data provided evidence for the existence of two major CCK8-containing pathways in turtles that have been previously described in mammals: a pathway from the supraoptic and paraventricular magnocellular nuclei to the external zone of the median eminence and neurohypophysis and a pathway from dorsal root ganglia to the dorsal horn of the spinal cord. Overall, the present results, in conjunction with several previous studies, indicate that CCK8 has had a relatively stable evolutionary history as a CNS neuropeptide among land vertebrates. The molecular structure of CCK 8 appears to have been largely (if not entirely) conserved, as has its concentration in many brain regions. A noteworthy exception to such conservatism in the localization of CCK8 is that the concentration of CCK8 in the telencephalon, particularly in the telencephalic cortex, is much lower in turtles than in mammals. The present results therefore suggest that CCK8 may not have become a prominent peptide in the telencephalic cortex (or its anatomical equivalents) until the evolution of neocortex in the mammalian lineage.
\end{abstract}

Cholecystokinin-8 Central nervous system Turtles Immunohistochemistry

CHOLECYSTOKININ (CCK) is a thirty-three amino acid peptide that stimulates gall bladder contraction and pancreatic enzyme secretion and is found in high concentration in the proximal small intestine, where it is localized to a specific class of gut endocrine cells. Cholecystokinin is also found in great abundance in neurons and fibers of the nervous system, where shorter peptide fragments of CCK, in particular the C-terminal octapeptide (CCK8), predominate $[4,21,44]$. The precise role of CCK8 in the nervous system is uncertain, but it is clear that CCK8 displays many of the characteristics of a neurotransmitter, particularly in terms of its localization, release and receptor-mediated actions on postsynaptic neurons $[6,20,75]$. Among the many peptides found in the mammalian brain, $\mathrm{CCK} 8$ is distinguished by being one of the few peptides (together with VIP) that is found in a higher concentration in the cerebral cortex than in any other neural region $[8,24,55,76]$. Although the gall bladder and, to a lesser extent, the pancreas appear to be phylogenetically old features of the vertebrate GI tract, the type of cortex that predominates in the mammalian cerebral hemispheres (i.e., neocortex) is a more recent feature of vertebrate phylogeny [54,57]. Nonetheless, comparative neuroanatomical studies during the last decade have shown that large portions of the nonmammalian telencephalon, though not organized into a neocortical tissue such as in mammals, are comparable to mammalian neocortex in terms of histochemistry, connections and functions $[37,54,56,57$, 80]. Thus, it might be expected that CCK8 or a CCK8-like peptide be prominent in the neocortical-equvalent tissue of nonmammals. Previous studies have shown that CCK-like peptides are present in both the brain and gut of members of many different ancient animal groups, including annelid worms, dungeness crabs and lampreys [26, 33, 42]. The $\mathrm{CCK}$-like materials present in the gut and brain of the mem- 
ABBREVIATIONS

\begin{tabular}{|c|c|c|c|}
\hline a & Area a (Riss, Halpern and Scalia [73]) & $\mathrm{nPH}$ & Nucleus periventricularis hypothalami \\
\hline AP & Area pretectalis & nPM & Nucleus profundus mesencephali \\
\hline AT & Area triangularis & $\mathrm{nS}$ & Nucleus septalis \\
\hline BA & Nucleus basalis amygdalae & $\mathrm{nSL}$ & Nucleus septalis lateralis \\
\hline $\mathrm{CA}$ & Nucleus centralis amygdalae & $\mathrm{nSM}$ & Nucleus septalis medialis \\
\hline $\mathrm{Cb}$ & Cerebellum & nSO & Nucleus supraopticus \\
\hline $\mathrm{CbL}$ & Nucleus cerebellaris lateralis & $\mathrm{nSP}$ & Nucleus suprapenduncularis \\
\hline ChM & Nucleus cerebellaris medialis & nSPM & Nucleus suprapeduncularis medialis \\
\hline $\mathrm{cd}$ & Cortex dorsalis & nTOL & Nucleus tracti olfactorii lateralis \\
\hline $\mathrm{cdm}$ & Cortex dorsomedialis & nTS & Nucleus tracti solitarii \\
\hline $\mathrm{cm}$ & Cortex medialis & $\mathrm{nVH}$ & Nucleus ventromedialis hypothalami \\
\hline $\mathrm{CN}$ & Core nucleus of the DVR & n III & Nucleus nervi oculomotorius \\
\hline $\mathrm{CO}$ & Chiasma opticum & n IV & Nucleus nervi trochlearis \\
\hline Co & Cochlear nuclei & n VI & Nucleus nervi abducens \\
\hline $\mathrm{CP}$ & Commissura posterior & n VII & Nucleus nervi facialis \\
\hline $\mathrm{cp}$ & Cortex pyriformis & $\mathrm{n} X$ & Nucleus motorius dorsalis nervi vagi \\
\hline d & Area d (Riss, Halpern and Scalia [73]) & $\mathrm{n}$ XII & Nucleus nervi hypoglossi \\
\hline d IV & Decussatio nervi trochlearis & OI & Oliva inferior \\
\hline DLA & Nucleus dorsalateralis anterior & OS & Oliva superior \\
\hline DMA & Nucleus dorsomedialis anterior & PA & Paleostriatum augmentatum \\
\hline DSOD & Dorsal nucleus of the supraoptic decussation & $\mathrm{Pb}$ & Nucleus parabrachialis \\
\hline DVR & Dorsal ventricular ridge of the telencephalon & PD & Peduncularis dorsalis fasciculi prosencephali lateralis \\
\hline FD & Funiculus dorsalis & $\mathrm{PH}$ & Primordium hippocampi \\
\hline FL & Funiculus lateralis & $\operatorname{PrV}$ & Nucleus princeps nervi trigemini \\
\hline FLM & Fasciculus medialis longitudinalis & PT & Pallial thickening \\
\hline FRL & Formatio reticularis lateralis mesencephali & PV & Peduncularis ventralis fasciculi prosencephali lateralis \\
\hline FV & Funiculus ventralis & $\mathbf{R}$ & Nucleus rotundus \\
\hline GC & Griseum centrale & Rai & Nucleus raphes inferior \\
\hline GCL & Granule cell layer & Ras & Nucleus raphes supcrior \\
\hline GLd & Nucleus geniculatus lateralis pars dorsalis & $\operatorname{Re}$ & Nucleus reuniens \\
\hline GLv & Nucleus geniculatus lateralis pars ventralis & $\mathrm{Ri}$ & Nucleus reticularis inferior \\
\hline GP & Globus pallidus & Ris & Nucleus reticularis isthmi \\
\hline HL & Nucleus habenularis lateralis & $\mathrm{Rm}$ & Nucleus reticularis medialis \\
\hline HM & Nucleus habenularis medialis & ROB & Radix opticum basalis \\
\hline IP & Nucleus interpeduncularis & Rs & Nucleus reticularis superior \\
\hline Imc & Nucleus isthmi pars magnocellularis & $\mathrm{Ru}$ & Nucleus ruber \\
\hline Ipc & Nucleus isthmi pars parvocellularis & SGC & Stratum griseum centrale \\
\hline LA & Nucleus laminaris of the torus semicircularis & SGD & Nucleus substantiae griseae dorsalis \\
\hline LGE & Laminaris granularis externa & SGF & Stratum griseum et fibrosum superficiale \\
\hline LGI & Laminaris granularis interna & SGP & Stratum griseum profundum \\
\hline LL & Lateral lemniscus & SGV & Substantiae griseae ventralis \\
\hline LM & Nucleus lentiformis mesencephali & SM & Stria medullaris \\
\hline LoC & Locus coeruleus & Sm & Supramamillary region \\
\hline MA & Nucleus medialis amygdalae & SN & Substantia nigra \\
\hline MC & Mitral cell layer & SO & Stratum opticum \\
\hline ME & Median eminence & ST & Stria terminalis \\
\hline ML & Molecular layer & Ta & Nucleus tangentialis \\
\hline M V & Nucleus mesencephalicus nervi trigemini & Tel & Telencephalon \\
\hline $\mathrm{m} \mathrm{V}$ & Nucleus motorius nervi trigemini & $\mathrm{TeO}$ & Tectum opticum \\
\hline NHy & Neurohypophysis & TO & Tractus opticus \\
\hline NPd & Nucleus pretectalis dorsalis & TOI & Tractus opticus, pars lateralis \\
\hline $\mathrm{NPv}$ & Nucleus pretectalis ventralis & TOm & Tractus opticus, pars medialis \\
\hline $\mathbf{N}$ V & Nervus trigemini & $\operatorname{TrL}$ & Tract of Lissauer \\
\hline N VIII & Nervus octavus & TSC & Torus semicircularis \\
\hline nAmb & Nucleus ambiguus & TTd & Nucleus descendens nervi trigemini \\
\hline nBOR & Nucleus of the basal optic root & TuOl & Tuberculum olfactorium \\
\hline nCA & Nucleus commissuralis anterioris & TT & Tractus tectothalamicus \\
\hline $\mathrm{nDB}$ & Nucleus fasciculus diagonalis Brocae & VeD & Nucleus vestibularis descendens \\
\hline $\mathrm{nDCP}$ & Nucleus dorsalis commissuralae posterioris & VeL & Nucleus vestibularis lateralis \\
\hline nFLM & Nucleus fasciculi longitudinalis medialis & $\mathrm{VeS}$ & Nucleus vestibularis superior \\
\hline $\mathrm{nMH}$ & Nucleus medialis hypothalami & VP & Ventral paleostriatum \\
\hline
\end{tabular}


bers of these vertebrate and invertebrate groups, however, differ in chemical structure from the CCK-related peptides found in mammalian tissues. In the present study, we have studied turtles, a member of a class of vertebrates (i.e., reptiles) immediately ancestral to mammals, in order to gain insight into the recent evolutionary history of CCK-related peptides in the vertebrate brain. A previous study [43] has suggested that a CCK-like peptide is present in duodenal secretory cells in turtles, based on the immunological reactivity of this peptide to several different regionally-specific antisera against $\mathrm{CCK}$.

\section{METHOD}

Studies were carried out on red-eared turtles (Pseudemys scripta), painted turtles (Chrysemys picta) and mud turtles (Kinosternum subrubrum). They were maintained in a heated $\left(25-30^{\circ} \mathrm{C}\right)$ open air aquarium with an artificial daynight cycle (14 hours light-10 hours darkness). A C-terminally directed antiserum against CCK8 (R5) was used in the present study for radioimmunoassay and immunohistochemistry. The details of the production and characterization of this antiserum have been described previously [9]. Although the antiserum does not distinguish between CCK8 and gastrin, the bulk of the CCK-like material in turtle brain was found in the present study to co-elute with CCK8-sulfate in gradient elution HPLC.

\section{Biochemical Studies}

The brains were removed from 3 freshly decapitated turtles (one red-eared turtle and 2 mud turtles) and dissected into ten discrete subdivisions: (1) olfactory bulbs, (2) telencephalic cortex, (3) telencephalic dorsal ventricular ridge (DVR) plus rostral pyriform (olfactory) cortex, (4) basal telencephalon including basal ganglia and septum, (5) thalamus and habenula, (6) hypothalamus and neurohypophysis, (7) tectum and pretectum, (8) tegmentum, (9) cerebellum and (10) rhombencephalon. In addition, the first $4-5$ cervical spinal segments were dissected from each animal. All dissections were carried out on ice. The approximate internal subdivisions along which the telencephalon, midbrain and hindbrain were subdivided for radioimmunoassay (RIA) have been described previously [72]. All tissue samples were blotted and weighed. The tissue was boiled in water, sonicated in ice cold $0.1 \mathrm{~N} \mathrm{HCl}$ and an aliquot removed from each sample for Lowry protein assay [47]. After each tissue extract was clarified by centrifugation, an aliquot of the supernatant was removed for RIA and neutralized with an equal volume of $0.1 \mathrm{~N} \mathrm{NaOH}$. The RIA procedure used ${ }^{12} \mathrm{I}$-Gastrin 17-I, with CCK8-sulfate as the standard. The RIA procedure has been described in greater detail previously [9]. For HPLC, aliquots from the supernatants were combined, clarified by centrifugation and injected onto an Altech column $(0.46 \times 2.5$ $\mathrm{cm}$ ) and eluted with a linear gradient of 20-60\% acetonitrile in the presence of $0.9 \%$ trifluoroacetic acid over 40 minutes. One minue fractions were collected at a flow rate of 1 $\mathrm{ml} / \mathrm{minute}$. The HPLC fractions were dried in a Savant vacuum centrifuge, resuspended in water and an aliquot removed for CCK8 RIA. CCK8-sulfate and Human Gastrin 17-I were used as standards in the present study and were detected optically and with CCK8 RIA. Several previous studies by one of us as well as by other investigators have shown that gradient elution HPLC systems similar to the present one, as well as a variety of other HPLC systems, provide clear and consistent separation of CCK8-sulfate, CCK8-desulfate, CCK33, CCK4, caerulein, Human Gas-
trin17-I and Human Gastrin17-II ([4, 7, 11, 53] Beinfeld, unpublished observation).

\section{Immunohistochemical Studies}

Turtles were anesthetized deeply with ketamine or sodium pentobarbital and perfused through the heart with $6 \%$ dextran in $0.1 \mathrm{M}$ phosphate buffer at $\mathrm{pH} 7.4(\mathrm{~PB})$, followed by a solution of $4 \%$ paraformaldehyde in PB. The brains (with a few segments of cervical spinal cord still attached) were dissected from the skull, immersed in $4 \%$ paraformaldehyde in $0.1 \mathrm{M}$ phosphate buffer ( $\mathrm{pH} \mathrm{10.4)}$ for 2-18 hours, and then immersed in a 30\% sucrose-PB solution for 2 days. The brains and spinal cord were then sectioned frozen at $35 \mathrm{mi}$ crons on a sliding microtome. The indirect immunofluorescence procedure $[16,84]$ and the peroxidase-antiperoxidase (PAP) procedure [78] were used to localize CCK8 in the brain and spinal cord tissue sections. The details of our immunohistochemical techniques have been described elsewhere [70-72]. Briefly sections were washed three times in $\mathrm{PB}$ and incubated in the $\mathrm{R} 5$ antiserum against CCK8. Tissue incubations were carried out for 12-60 hours using a primary antiserum dilution of 1:1000. All antisera (primary and secondary) were diluted with PB containing $0.3 \%$ Triton $\mathrm{X}-100$. Following the incubation in primary antiserum, tissue was washed three times in PB and then processed according to either the indirect immunofluorescence procedure or the PAP procedure. For the immunofluorescence procedure, tissue was incubated in a secondary antiserum (raised in goat and directed against rabbit IgG) conjugated to fluorescein isothyocyanate (FITC) (Miles Laboratories) at a dilution of 1:50 for 1 hour at room temperature. Following the incubation in the FITC-conjugated secondary antiserum, sections were washed three times in $\mathrm{PB}$, mounted on gelatin-coated slides and coverslipped in a 9:1 solution of glycerol and $.05 \mathrm{M}$ carbonate buffer (pH 9.0). Sections were then examined with a Leitz Orthoplan microscope using a Ploem epi-illumination fluorescence microscopy system. For the PAP method, following incubation in the primary antiserum, sections werc incubated at a 1:50 dilution for one hour at room temperature in an unlabeled secondary antiserum that was raised in goat and directed against rabbit IgG (Miles Laboratories). Following three washes in PB, sections were incubated in PAP (antiperoxidase raised in rabbit) for one hour at room temperature at a dilution of 1:200. Sections were then washed three times in $\mathrm{PB}$ and reacted in a solution of diaminobenzidine (DAB) and $\mathrm{H}_{2} \mathrm{O}_{2}$ (100 mg DAB/100 ml $0.1 \mathrm{M}$ cacodylate buffer $\left(\mathrm{pH} \mathrm{7.2)/0.5 \%} \mathrm{H}_{2} \mathrm{O}_{2}\right)$ to demonstrate the location of the immunologically bound peroxidase. Sections were then washed, mounted on subbed slides and coverslipped with Permount. Specificity of the immunoreactivity was assessed by preabsorbing the primary antiserum with a $10 \mu \mathrm{M}$ concentration of synthetic CCK8. Terminology for the turtle brain is as used previously $[63,72]$.

Injections of colchicine $(100 \mu \mathrm{g}$ colchicine in $6 \mu \mathrm{l}$ distilled water) were made into the lateral ventricle of several turtles. Stereotaxic procedures were used with turtles under ketamine anesthesia [63]. Colchicine-treated turtles were sacrificed as described above $2-5$ days after the injection and the brains processed according to the immunohistochemical procedures described.

\section{RESULTS}

\section{Biochemical Studies}

The RIA data for the levels of CCK8 in the different re- 
TABLE 1

THE AMOUNT OF CCK8 IN THE DIFFERENT REGIONS OF TURTLE BRAIN, AS MEASURED BY RIA

\begin{tabular}{|c|c|c|c|}
\hline Region & $\begin{array}{l}\text { pg CCK8/ } \\
\text { region }\end{array}$ & $\begin{array}{c}\text { pg } \mathrm{CCK} 8 / \mathrm{mg} \\
\text { tissue }\end{array}$ & $\begin{array}{c}\mathrm{pg} \mathrm{CCK} 8 / \mu \mathrm{g} \\
\text { protein }\end{array}$ \\
\hline Olfactory Bulb & $650 \pm$ & $9.9 \pm 1.6$ & $0.14 \pm 0.01$ \\
\hline $\begin{array}{l}\text { Basal } \\
\text { Telencephalon }\end{array}$ & $1030 \pm 490$ & $10.2 \pm 3.2$ & $0.17 \pm 0.06$ \\
\hline Cortex & $2030 \pm 740$ & $10.4 \pm 4.2$ & $0.31 \pm 0.11$ \\
\hline $\begin{array}{l}\text { Dorsal } \\
\text { Ventricular } \\
\text { Ridge }\end{array}$ & $370 \pm 88$ & $2.6 \pm 0.7$ & $0.06 \pm 0.01$ \\
\hline $\begin{array}{l}\text { Hypothalamus/ } \\
\text { Neurohypophysis }\end{array}$ & $8200 \pm 2140$ & $212.1 \pm 72.8$ & $3.28 \pm 1.02$ \\
\hline $\begin{array}{l}\text { Thalamus/ } \\
\text { Epithalamus }\end{array}$ & $1170 \pm 220$ & $33.9 \pm 5.5$ & $0.81 \pm 0.39$ \\
\hline Tegmentum & $2790 \pm 500$ & $53.6 \pm 7.9$ & $0.96 \pm 0.15$ \\
\hline Tectum & $1480 \pm 340$ & $20.6 \pm 4.4$ & $0.33 \pm 0.05$ \\
\hline Cerebellum & $180 \pm 100$ & $4.9 \pm 2.9$ & $0.08 \pm 0.04$ \\
\hline Rhombencephalon & $6000 \pm 610$ & $50.7 \pm 10.8$ & $0.95 \pm 0.16$ \\
\hline Spinal Cord & $2370 \pm 710$ & $57.8 \pm 13.7$ & $0.73 \pm 0.17$ \\
\hline
\end{tabular}

Each values is the mean ( \pm SEM) for that structure for the three turtles assayed. The basal telencephalon tissue sample included the entire basolateral wall of the telencephalon (including the basal ganglia and ventral paleostriatum), the septum and basal parts of the amygdala. The dorsal ventricular ridge (DVR) sample included the DVR, most of the pyriform cortex, ventral parts of the pallial thickening and more dorsal parts of the amygdala. The tegmental and tectal samples each included parts of the torus semicircularis. The value for the total amount of CCK8 in the spinal cord indicates the amount present in $4-5$ spinal segments. The amount of CCK8 per mg tissue is based on the wet weight of the tissue.

gions of turtle brain are shown in Table 1. The highest levels of CCK8 were found in the hypothalamus/neurohypophysis extract. Although the thalamus, tegmentum, rhombencephalon and spinal cord contained the next highest levels of CCK 8, the levels in these structures were only 1/3-1/4 that found in the hypothalamus/neurohypophysis. Moderate amounts of CCK8 were found in cortex, basal telencephalon and the tectum. Very little CCK8 was found in the olfactory bulbs, dorsal ventricular ridge or cerebellum. Using HPLC, the bulk (87\%) of the CCK8-like immunoreactive material in turtle nervous system was found to co-elute with CCK8-sulfate (see Fig. 1). Two minor peaks of CCK8-like material (each representing $6.5 \%$ of the eluted CCK8-like material) were observed, one eluting before $\mathrm{CCK} 8$-sulfate and the other eluting after CCK8-sulfate. Based on the retention times observed for the different CCK-like peptides in previous studies employing gradient elution HPLC ([53] Beinfeld, unpublished observation), these minor peaks appear to represent a CCK33-like peptide and CCK8-desulfate, respectively.

\section{Immunohistochemical Studies}

The immunohistochemical data were consistent with the CCK8 RIA values for the CCK8 content of the different neural regions in turtle. A map of the distribution of specific (i.e., blockable by absorption of the antiserum with synthetic CCK8) CCK8-like immunoreactivity (CCK8LI) in turtle brain is shown in Figs. 2-10. Photomicrographs of CCK8-

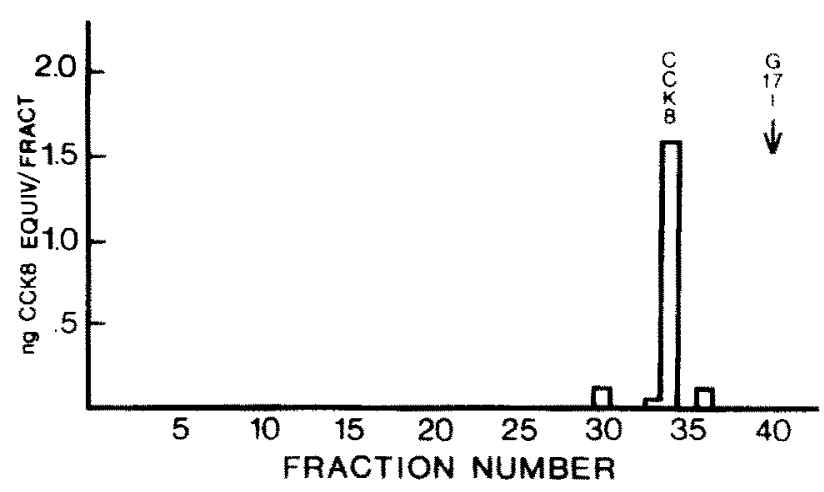

FIG. 1. Gradient elution HPLC profile of extract from turtle brain. The bulk of the CCK8-like material in turtle brain $(87 \%)$ co-elutes with CCK8-sulfate. The arrow (fraction 40) indicates the retention time of gastrin 17-I (G17-I) in this HPLC system. The small peaks of CCK8LI preceding (fraction 30) and following (fraction 36) CCK8sulfate each represent $6.5 \%$ of the total CCK8LI eluted in this HPLC system. As discussed in the text, these small peaks may represent CCK8-desulfate (fraction 36 ) and a high molecular weight peptide similar to CCK33 (fraction 30). No evidence was obtained for the presence in turtle nervous system of CCK4, which (as discussed in the text) should elute in fraction 21-22.

positive labeling in several neural regions is shown in Figs. 11-12. In general, more CCK8LI-containing perikarya were observed in colchicine-treated animals than in normal animals. In the case of some cell groups, CCK8LI-containing perikarya were not observed except in colchicine-treated turties. Although the bulk of the CCK8LI in turtle brain appears to be indistinguishable from CCK8-sulfate by the present HPLC system, the immunoreactive material observed in turtle nervous tissue with immunohistochemical methods is nonetheless referred to as "CCK8-like" because: (1) a small amount (13\%) of the CCK8-like material in turtle central nervous system did not co-elute with CCK8-sulfate, and (2) the predominant CCK8-like material in turtle nervous system may differ from CCK8-sulfate in ways not detectible by the present HPLC system. The amount of CCK8LI measured by RIA, in contrast, is referred to in terms of CCK8-equivalents (Table 1) because RIA measures the amount of immunoreactive material fuond in tissue in terms of its activity in relation to specific standard (in this case CCK8-sulfate).

Telencephalon. The most prominent regions containing CCK8LI in the telencephalon were the cortex and septum (see Figs. 2-7 and 11). A web of CCK8Ll-containing fibers and their terminals was found within the cell body layer of the cortex throughout the entire rostrocaudal and mediolateral extent of the cortex, including the entire extent of the medial, dorsomedial and dorsal cortices (see Fig. 11A). This web of fibers also was present in the pallial thickening, a lateral noncortical extension of the dorsal cortex. Labeled fibers of a similar appearance were also present but very sparse in the pyriform cortex. CCK8LI-containing fibers were also prominent throughout the septum (see Figs. 3 and $11 \mathrm{~B})$ and in the lateral septum appeared to surround unlabeled perikarya. Sparser labeled fibers were observed in the internal granular layer of the olfactory bulb, the olfactory tubercle, area a (anterior olfactory nucleus), the basal ganglia (including area $\mathrm{d}$, the paleostriatum augmentatum and the globus pallidus), the ventral paleostriatum and the basal, 

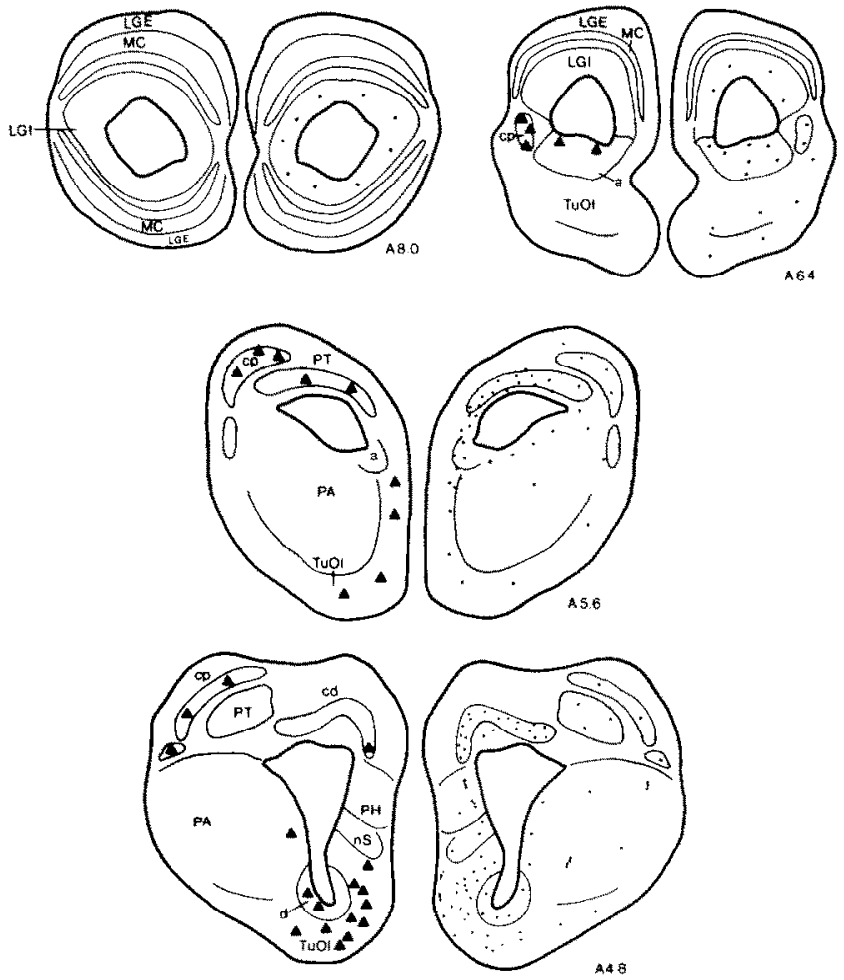

FIG. 2. Line drawings of transverse sections through turtle olfactory bulb and rostral telencephalon illustrating the location and relative density of CCK8LI-containing fibers and terminals (dots) and perikarya (triangles) observed with immunohistochemical techniques. Each triangle corresponds to 1-5 CCK8-labeled neurons. Numbers to the lower right indicate the anterior-posterior level of the section in stereotaxic coordinates [63].

medial and central amygdaloid nuclei (see Figs. 2-6). In contrast to the cortex, the dorsal ventricular ridge (DVR) contained very few CCK8LI-containing fibers, with only a few labeled fibers being evident among cell clusters in the superficial cell plate of the posterior DVR (as defined by Balaban [2]) (see Figs. 3-6). Despite the measurable amount of CCK8LI detected in the olfactory bulb by RIA, very few CCK8LI-containing fibers were observed in the olfactory bulb by immunohistochemistry (see Fig. 2). Cells containing CCK8LI were sparse in the telencephalon. A number were found in the olfactory tubercle at the ventromedial edge of the rostral telencephalon and a few lightly labeled cells were present in the lateral septal region, area d and PA. A number of additional lightly labeled cells were observed in cp and nTOL in colchicine-treated turtles. Labeled cells were only rarely observed, however, in the cortex and DVR, even in colchicinetreated turtles. Cortical neurons containing CCK8LI were largely restricted to the medial and dorsomedial cortices.

Diencephalon. Consistent with the RIA data, numerous CCK8LI-containing neurons and fibers were observed in the diencephalon, particularly in the hypothalamus and neurohypophysis (see Figs. 3-6). Fibers containing CCK8LI
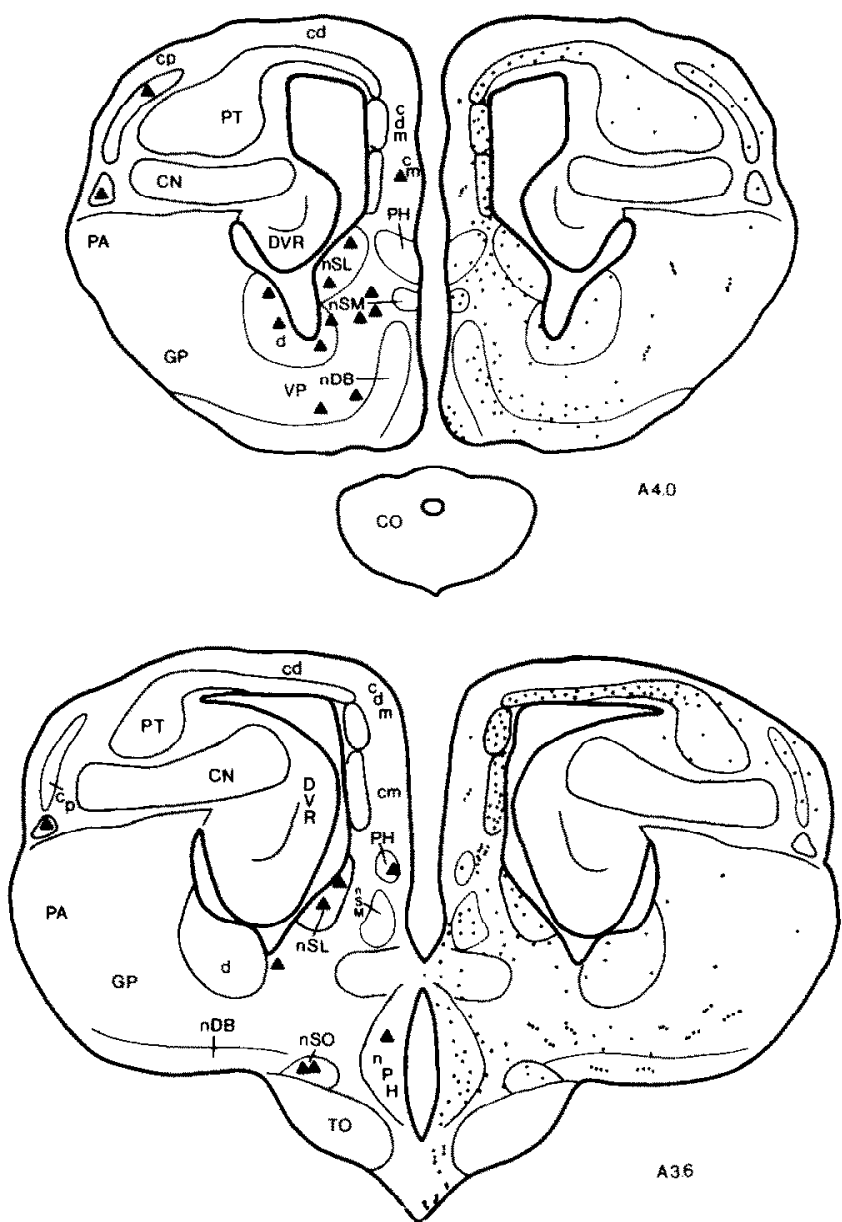

FIG. 3. Line drawings of transverse sections through slightly more caudal telencephalic levels of turtle brain than shown in Fig. 2. Dots and triangles in Figs. 3-10 indicate the relative density of CCK8LIcontaining fibers and perikarya, respectively, observed with immunohistochemical methods.

were observed throughout the hypothalamus, with a higher concentration in the periventricular hypothalamus than in the lateral hypothalamus. A prominent region of CCK8LIcontaining fibers was observed in the ventromedial hypothalamic region (see Fig. 5). The external zone of the median eminence and the neurohypophysis were particularly rich in CCK8LI-containing fibers (see Figs. 4-6 and 12A). Within the thalamus, CCK8LI-positive fibers were largely restricted to the perirotundal nuclei (dorsomedialis anterior and dorsolateralis anterior) (see Figs. 5-6 and 11D), with a few positive fibers also being present in the ventral lateral geniculate nucleus. Lateral parts of the medial habenular nucleus were also rich in CCK8LI-containing fibers. Neurons containing CCK8LI were observed in the supraoptic nucleus (see Figs. 3,4 and $11 \mathrm{C}$ ), the paraventricular region, the medial suprapeduncular nucleus, the lateral hypothalamic region, the arcuate region, the neurohypophysis and the region ventral to the medial hypothalamic nucleus (here termed the supramamillary region) (see Figs. 6, A0.8 and 12B).

Mesencephalon. CCK8LI-containing neurons and fibers were relatively sparse in the midbrain. Within the midbrain, the densest accumulations of CCK8LI-containing fibers 

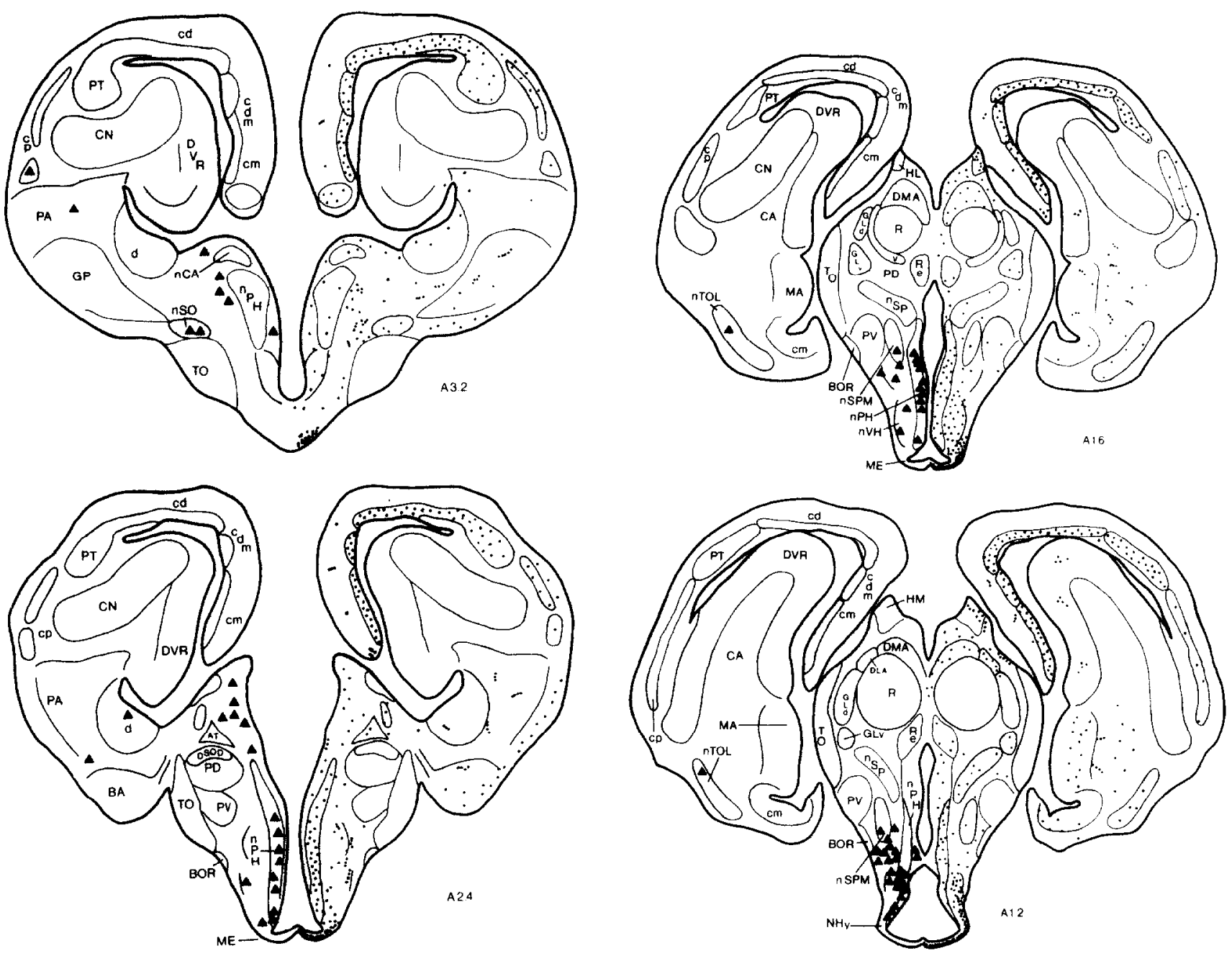

FIG. 4. Line drawings of transverse sections through the midtelencephalon and rostral diencephalon of turtle showing the distribution of CCK8LI-containing fibers and terminals and perikarya.

were observed in the area pretectalis, the intermediate and periventricular layers of the tectum, the midbrain periventricular gray, the medial tegmentum, the midline of the interpeduncular nucleus and the parvocellular isthmic nucleus (see Figs. 6-8). Sparse CCK8LI-containing fibers were observed in the stratum opticum of the tectum, scattered throughout the tegmentum and along the superficial rim of the magnocellular isthmic nucleus. CCK8LI-containing neurons were observed in the deep and, more rarely, intermediate tectal layers, the medial tegmentum and the laminar nucleus of the torus semicircularis. The numbers of perikarya containing CCK8LI were much greater in the tectum and the laminar nucleus of the torus semicircularis in colchicine-treated turtles than in normal turtles.

Rhombencephalon and spinal cord. Scattered CCK8LIcontaining fibers were found within the granule cell layer of the cerebellum (see Figs. 8-9). Within the isthmic region, CCK8LI-containing fibers were relatively dense in the central gray, in the locus coruleus, in and lateral to the nucleus of the lateral lemniscus and in the parabrachial region (see Figs. 7-8). Scattered CCK8LI-containing neurons were observed in a number of cell groups of the rostral rhomben-

FIG. 5. Line drawings of transverse sections through the caudal telencephalon and midtelencephalon of turtle showing the distribution of CCK8LI-containing fibers and terminals and perikarya.

cephalon in colchicine-treated turtles, including the nucleus of the lateral lemniscus, the locus coeruleus, the parabrachial region, the isthmic reticular formation and the region between TTd and nVII. Fibers containing CCK8LI were found within the raphe nuclei at all rostrocaudal levels of the rhombencephalon (see Figs. 7-10). More labeled fibers, however, were observed within the raphe at rostral levels than at caudal levels. Neurons containing CCK8LI were observed lateral to the superior nucleus of the raphe (see Fig. 7, P2.4). A dense accumulation of CCK8LI-containing fibers was observed in the ventrolateral rhombencephalon throughout its entire extent. These labeled fibers encompassed the principal nucleus of the trigeminal nerve, the motor nucleus of the trigeminal nerve, the nucleus of the descending tract of the trigeminal nerve, the motor nucleus of the facial nerve and lateral portions of the rhombencephalic reticular formation. More medial portions of the rhombencephalic reticular formation contained considerably fewer CCK8-positive fibers. At the level of the motor nucleus of the trigeminal nerve and the motor nucleus of the facial nerve, CCK8LI-containing fibers were observed to make prominent pericellular terminations on large neurons (see Fig. 8, P4.8; Fig. 9, P7.2). 

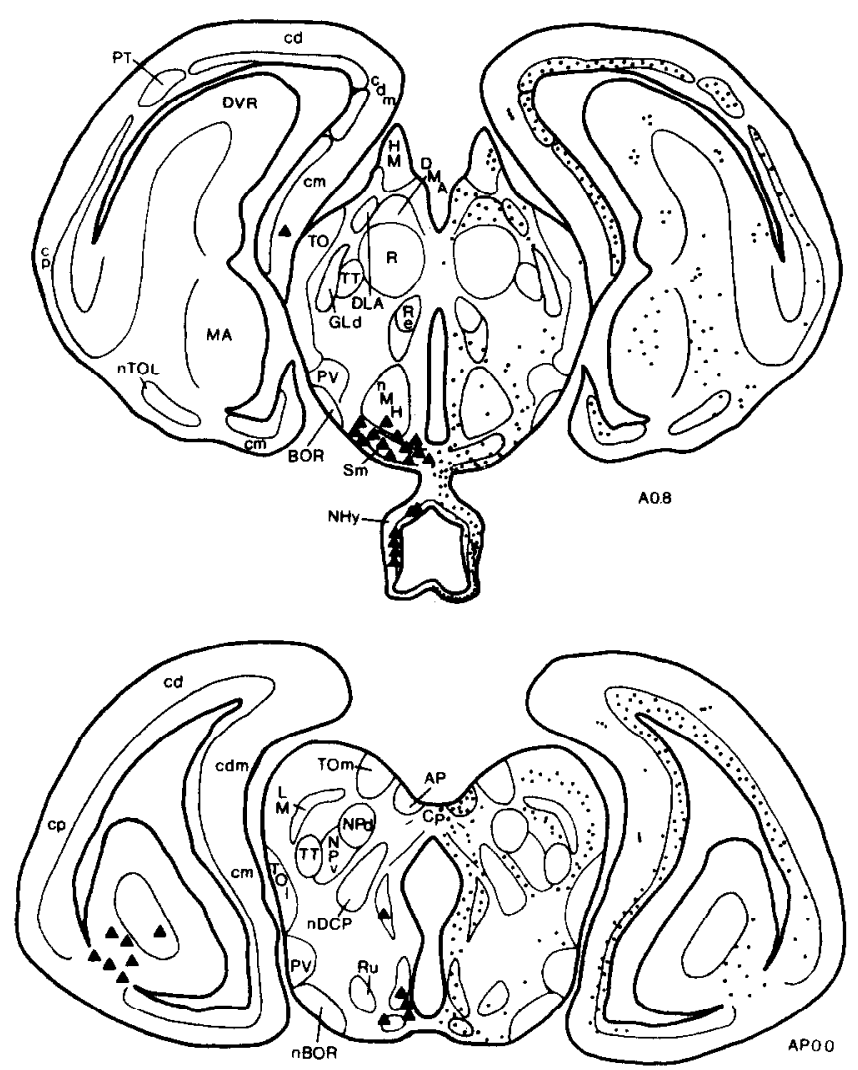

FIG. 6. Line drawings of transverse sections through the caudal telencephalon and the mesodiencephalic junctional region of turtle showing the distribution of CCK8LI-containing fibers and terminals and perikarya.
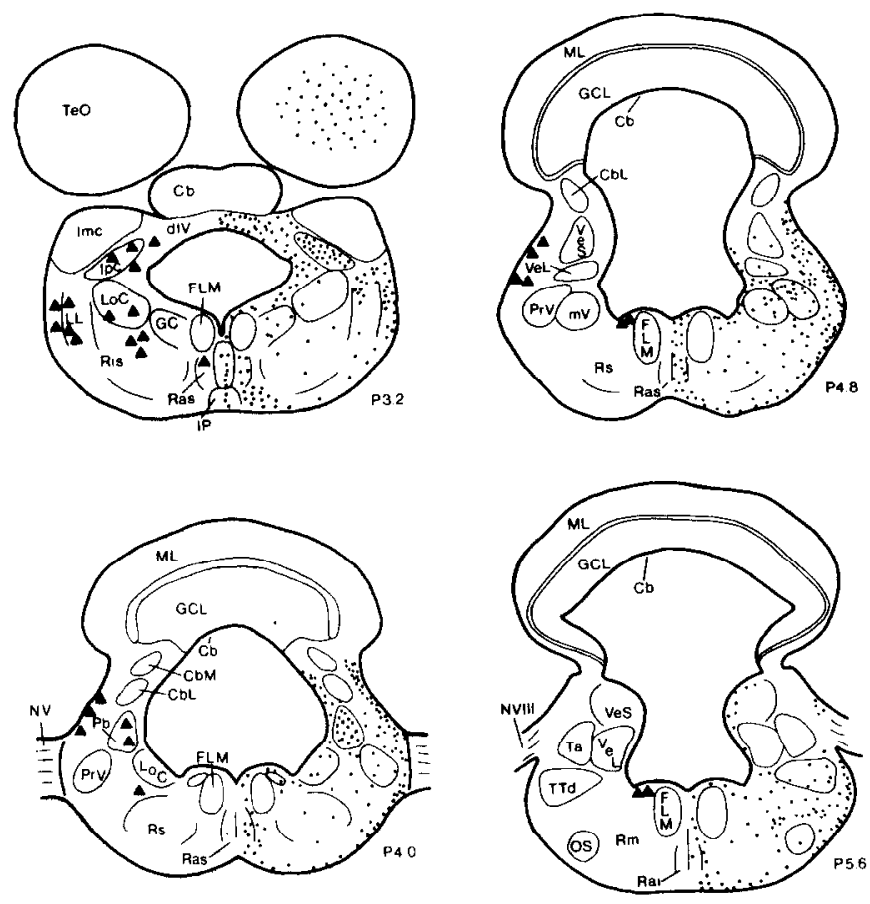

FIG. 8. Line drawings of transverse sections through the rostral rhombencephalon of turtle illustrating the distribution of CCK8LIcontaining fibers and terminals and perikarya.
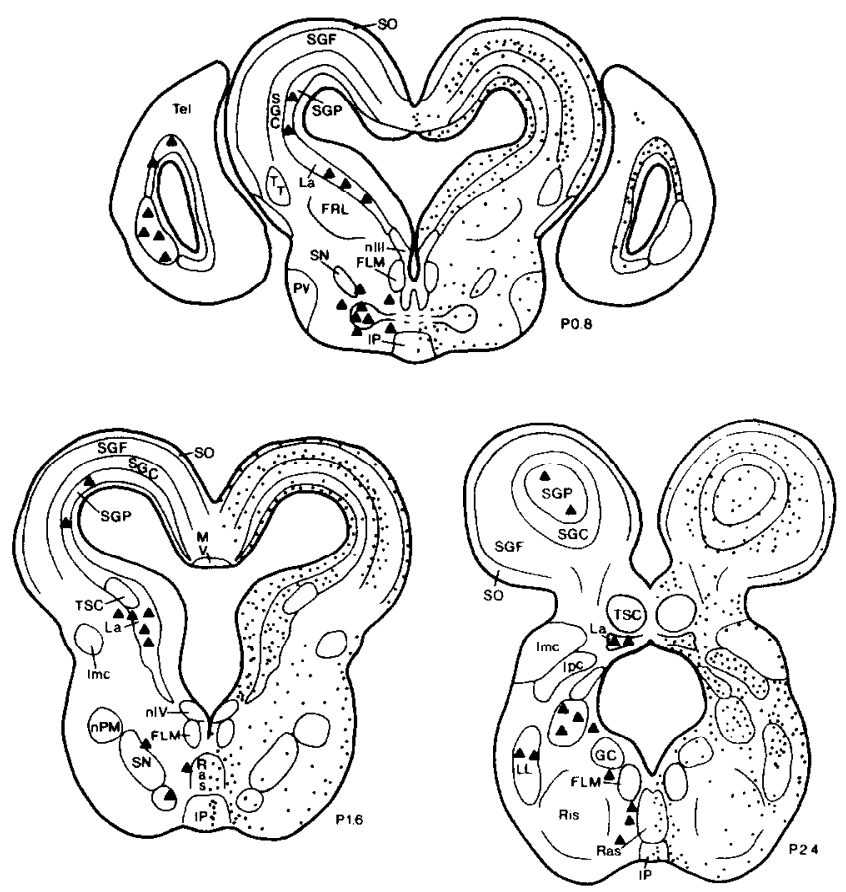

FIG. 7. Line drawings of transverse sections through the midbrain of turtle showing the distribution of CCK8LI-containing fibers and terminals and perikarya.
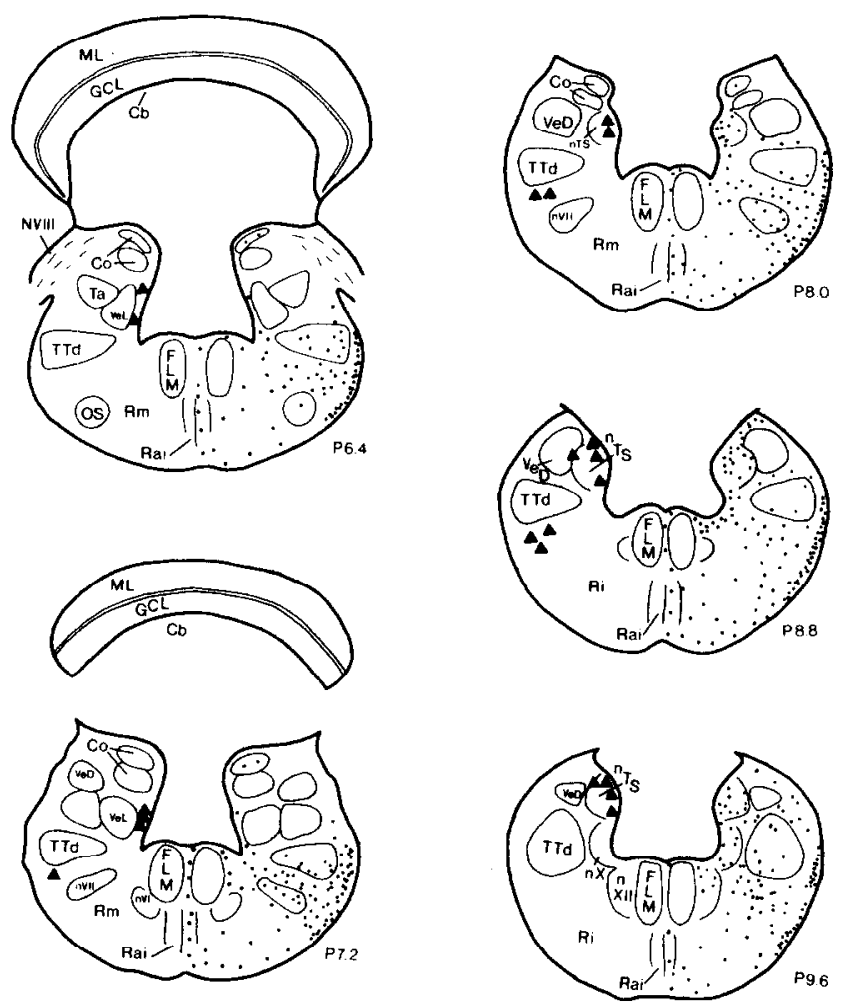

FIG. 9. Line drawings of transverse sections through the caudal rhombencephalon of turtle illustrating the distribution of CCK8LIcontaining fibers and terminals and perikarya. 

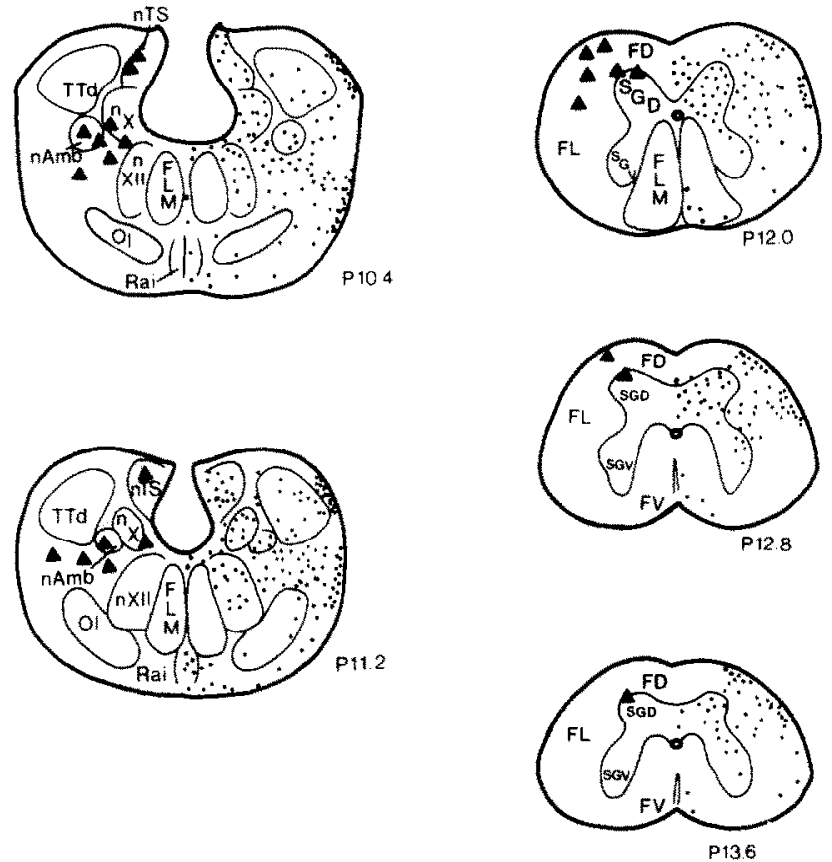

FIG. 10. Line drawings of transverse sections through the spinomedullary junction and the spinal cord in turtle illustrating the distribution of CCK8LI-containing fibers and terminals and perikarya.

Numerous CCK8LI-containing neurons and fibers were observed in the nucleus of the solitary tract at all levels of the solitary tract (see Fig. 9, 10 and 12C). A number of CCK8LI-containing fibers were also observed in the motor nucleus of the vagus nerve and nucleus ambiguus. Neurons containing CCK8LI were observed in the motor nucleus of the vagus and in and around nucleus ambiguus (see Fig. 10, P10.4 and P11.2). Within the spinal cord, CCK8LIcontaining fibers were observed in the zone (or tract) of Lissauer (see Fig. 12D), in the lateral funiculus, in the dorsal horn and in the lateral portions of the ventral horn (see Fig. 10). The CCK8LI-containing fibers of the zone of Lissauer were continuous rostrally with CCK8LI-containing fibers lateral to the nucleus of the descending tract of the trigeminal nerve. These CCK8LI-containing fibers may represent terminals of dorsal root fibers and terminals of trigeminal nerve fibers, respectively. In colchicine-treated turtles, CCK8LIcontaining neurons were observed in the area of the tract of Lissauer and in the dorsal horn of the spinal cord.

\section{DISCUSSION}

In the present study, substantial amounts of a CCK-like peptide were found in the turtle nervous system and the bulk of this CCK-like material was found to co-elute in gradient elution HPLC with CCK8-sulfate. Beinfeld and her coworkers have previously shown that a variety of HPLC sys- tems, including ones similar to the present HPLC system, yield clear and consistent separation of CCK8-sulfate, CCK8-desulfate, CCK33, CCK4, Gastrin 17-I and Gastrin 17-I ([4, 5, 7, 11] Beinfeld, unpublished observation). Other investigators [53] have also used gradient elution HPLC systems similar to that used in the present study and found clear separation of the major CCK peptides. Thus, the present results indicate that: (1) the major form of $\mathrm{CCK}$ in turtle brain (representing $87 \%$ of the total CCK8LI measured by the R5 antiserum) is distinct from CCK8-desulfate. CCK33, CCK4 and the gastrin peptides, and (2) the major CCK8-like peptide in the turtle brain is identical to CCK8sulfate or differs from CCK8-sulfate in ways not detectible by our HPLC system. Although the elution profile of the CCK8-related peptide caerulein was not examined in our present HPLC system, it appears very likely that the major CCK8-like peptide in turtle brain is distinct from caerulein. Caerulein can be readily separated from CCK8-sulfate by a variety of procedures (e.g., fractionation on Sephadex columns, [18,85] or isocratic elution HPLC, [18] Beinfeld, unpublished observation), including ones less sensitive than used here. Further, although caerulein was originally discovered in amphibian skin, caerulein does not appear to be present in the amphibian brain or retina (as further discussed below) $[18,85]$.

Two minor peaks of CCK8LI (each representing $6.5 \%$ of the total CCK8LI eluted) were observed in the present HPLC study, one occurring shortly before the major CCK8LI peak (fraction 30) and one occurring shortly after the major CCK8LI peak (fraction 36). The latter minor peak may represent $\mathrm{CCK} 8$-desulfate since this peptide has been shown to elute shortly after CCK8-sulfate in previous HPLC studies $[4,7,11]$. Several lines of evidence suggest that the small peak at fraction 30 may indicate the presence of a CCK33-like peptide in the turtle nervous system. Based on previous HPLC studies using gradient elution systems similar to that used in the present study (unpublished studies by M.C. Beinfeld using a Supelco column and a linear gradient of 20-50\% acetonitrile), we would expect that CCK33 should elute in fraction $29-30$ in the present HPLC system. Since the present extraction procedure (boiling followed by acidification) has previously been shown to effectively extract both high and low molecular weight forms of CCK $[53,79]$ and since the antiserum used in the present study does crossreact completely with CCK33, the peak observed at fraction 30 in the present study could represent a high molecular weight peptide similar to CCK33. It would seem likely that this peptide differ in structure somewhat from mammalian CCK33 since previous immunochemical studies have shown that the high molecular weight CCK-like peptides of crocodilian gut differ from mammalian CCK33 [13]. The putative CCK33-like peptide of turtle nervous system may, nonetheless, be sufficiently similar to CCK33 to show a retention time in our HPLC system similar to that of CCK33.

We have also used the present HPLC system to characterize the CCK-like materials present in the telencephalic cortex of turtle [68]. We found that $87 \%$ of the CCK8LI in

\section{FACING PAGE}

FIG. 11. Photomicrographs of CCK8-labeling in PAP-stained transverse sections through the turtle brain showing: (A) the CCK8-containing fibers in the cellular layer of telencephalic cortex; (B) labeled terminals in the region of the lateral septal nucleus; (C) labeled neurons in the supraoptic nucleus; (D) labeled fibers and terminals in nucleus dorsomedialis anterior, immediately above the unlabeled nucleus rotundus. Medial is to the left in $A$ and to the right in $B-D$. Scale bars: $A=250$ microns; $B-D=100$ microns. 


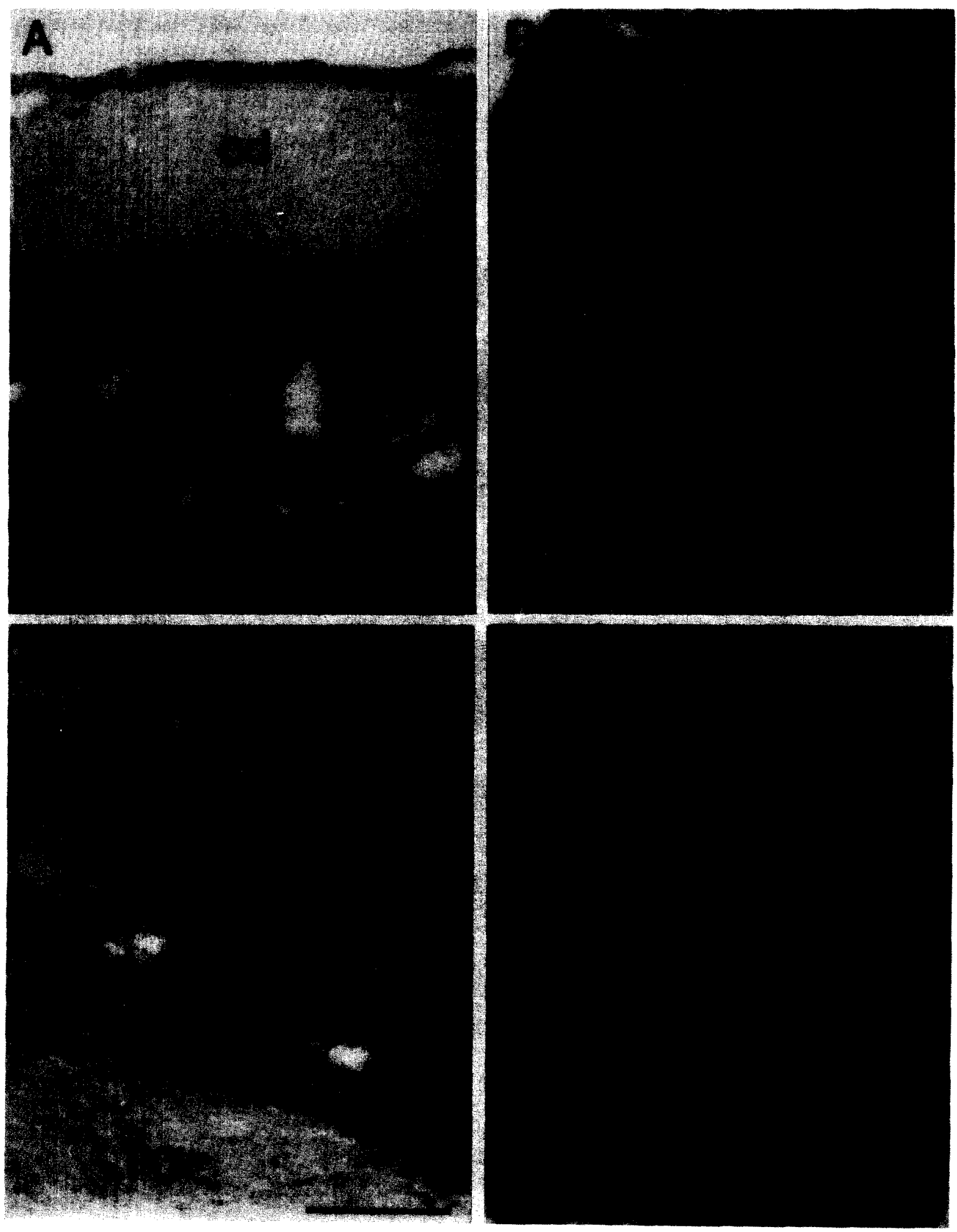


turtle cortex co-eluted with CCK8-sulfate and that $9.2 \%$ of the CCK8LI in turtle cortex eluted in fraction 30 . Thus, gradient elution HPLC of whole turtle brain extract as well as extract of a specific region of turtle brain have shown that there consistently appear to be two CCK-related peptides in turtle brain, a predominant peptide ( $87 \%$ of the total) that is highly similar or identical to CCK8-sulfate and a less abundant peptide (6-9\% of the total) that presumably represents a high molecular weight form of CCK similar to CCK33. No evidence was obtained in the study of the turtle cortex or in the present study for the presence of CCK4 in the turtle nervous system (CCK4 should elute in fraction 21-22 in the present HPLC system, M. C. Beinfeld, unpublished observation [53]). Since our anti-CCK8 antiserum is specific for the C-terminal pentapeptide of CCK8, it is possible, however, that small amounts of CCK-related peptides, such as CCK 4 , are present in turtle nervous system but were not detected by our RIA analysis of the HPLC fractions.

Previous studies of the reptilian gut have indicated that, as in mammals, CCK-like material is found in endocrine cells of the upper intestinal tract (while gastrin-like material is found in endocrine cells of the stomach) $[13,19,43]$. Using several regionally specific antisera, Larsson and Rehfeld [43] have found that the sequence of the last nine amino acids of the C-terminus of the CCK-like peptide in turtle GI tract is immunochemically indistinguishable from that of mammalian CCK. As noted above, Buchan et al. [13], however, have shown that the midportion of alligator CCK (corresponding to positions $9-20$ of mammalian CCK) is immunochemically distinct from the midportion of mammalian CCK. The present identification of a peptide in the turtle central nervous system that is highly similar or identical to mammalian CCK8-sulfate and the previous discovery of a peptide in the upper intestinal tract of turtle that is highly similar (if not identical) in its C-terminus to mammalian CCK are not surprising in light of recent findings in amphibians. In frogs also, the bulk of the CCK-like material found in the nervous system and retina is indistinguishable from CCK8sulfate by HPLC or gel filtration chromatography $[11,18,27$, 85]. Although caerulein is present in amphibian skin, neither caerulein nor a caerulein-like peptide have been detected in the amphibian brain [18]. CCK-like peptides are also present in high concentration in the upper intestinal tract of frogs and one of these CCK-like peptides has been found to be indistinguishable from CCK8-sulfate [18]. The results in reptiles and frogs, thus, clearly suggest that a CCK-like peptide (which contains CCK8-sulfate or a highly similar peptide at its C-terminus) has been present in intestinal cells and a peptide highly similar or identical to CCK8-sulfate has been present in neurons since the very beginnings of the evolution of land vertebrates (if not earlier). It seems likely that the physiological roles of gut CCK and brain CCK8 in the first land vertebrates were similar to those in modern mammals. The findings on CCK 8 in the nervous system of frogs and turtles suggest that CCK8 has had a considerably more conservative evolutionary history in terms of its chemical structure than have other neuropeptides such as LHRH [38,39], neurotensin [14], substance $P[66,68,72]$, and vasopressin and oxytocin [1].

A number of lines of evidence indicate that CCK 8 acts as a neurotransmitter or neuromodulator within the mammalian nervous system: it is localized in neurons and their terminals $[25,34,44,46,61,64,81]$, it is released in a calcium dependent fashion by depolarization $[25,52,62]$, it binds to specific receptor sites $[35,77]$ and it has an excitatory effect on neurons $[22,36,41,60]$. The presence of CCK 8 in widespread areas of the turtle brain with regional concentrations largely similar to those found in mammals $[9,10]$ suggests that CCK8 also acts as a neurotransmitter/neuromodulator in reptilian brain. Further, the present immunohistochemical data suggests that CCK 8 may act as a neuroactive agent in many of the same systems in reptiles as presumed to be the case in mammals. Fibers containing CCK8LI were observed in Lissauer's zone of the spinal cord and along the margin of the rhombencephalon lateral to the nucleus of the descending tract of the trigeminal nerve. Since these sites of CCK8LI-containing fibers are regions of termination of dorsal root fibers and trigeminal nerve fivers, respectively, CCK8LI may be present in the terminals of dorsal root and trigeminal nerve primary afferent fibers, as reportedly the case in mammals [48]. The distribution of CCK8LI in the rhombencephalon of turtle is also similar to that previously reported in mammals, with numerous CCK8LI-containing fibers being present in the parabrachial region, along the raphe, in more lateral portions of the rhombencephalic reticular formation and in the vagal motor nucleus [46]. In turtle, numerous CCK8LI-containing neurons and fibers are present in the nucleus of the solitary tract at all rostrocaudal levels. The presence of CCK8LI-containing neurons and fibers in the nucleus of the solitary tract has also been reported in mammals $[40,58]$. In turtles, CCK8LI was also observed in neurons of the supraoptic nucleus and the paraventricular hypothalamic region and in fibers of the external zone of the median eminence and neurohypophysis, as reportedly the case in mammals and amphibians $[23,46$, 81]. The extensive population of labeled cells spanning the medial suprapeduncular nucleus of the hypothalamus, the lateral hypothalamic region and the supramamillary region of the hypothalamus may be comparable to the CCK8LIcontaining neurons reported in the supramamillary cell group and adjacent regions of the hypothalamus of mammals $[15,34]$. In addition, numerous substance P-like immunoreactivity (SPLI)-containing neurons are present in these same regions in both turtles and mammals $[45,68,72]$. In turtles, SPLI and CCK8LI co-occur in individual neurons of this hypothalamic cell field [68]. This SPLI/CCK8LIcontaining cell field appears to give rise to the CCK8LIcontaining fibers present in telencephalic cortex, fibers which also contain SPLI $[17,68]$. Finally, in colchicinetreated turtles, a number of CCK8LI-containing neurons were evident in the ventral tegmental area (or medial tegmentum) of turtles, particularly at more caudal levels of the

\section{FACING PAGE}

FIG. 12 Photomicrographs of CCK8-labeled PAP stained transverse sections through the turtle brain showing: (A) labeled fibers and terminals in the external zone of the median eminence; (B) labeled neurons in the supramamillary region of the diencephalon; (C) labeled neurons in the rostral nucleus of the solitary tract; (D) labeled fibers and terminals in dorsolateral funiculus and Lissauer's zone of the spinal cord. Medial is to the left in all photomicrogrphs. Scale Bars: $A, C$, and $D=100$ microns; $B=150$ microns. All abbreviations are found in the list of abbreviations. 


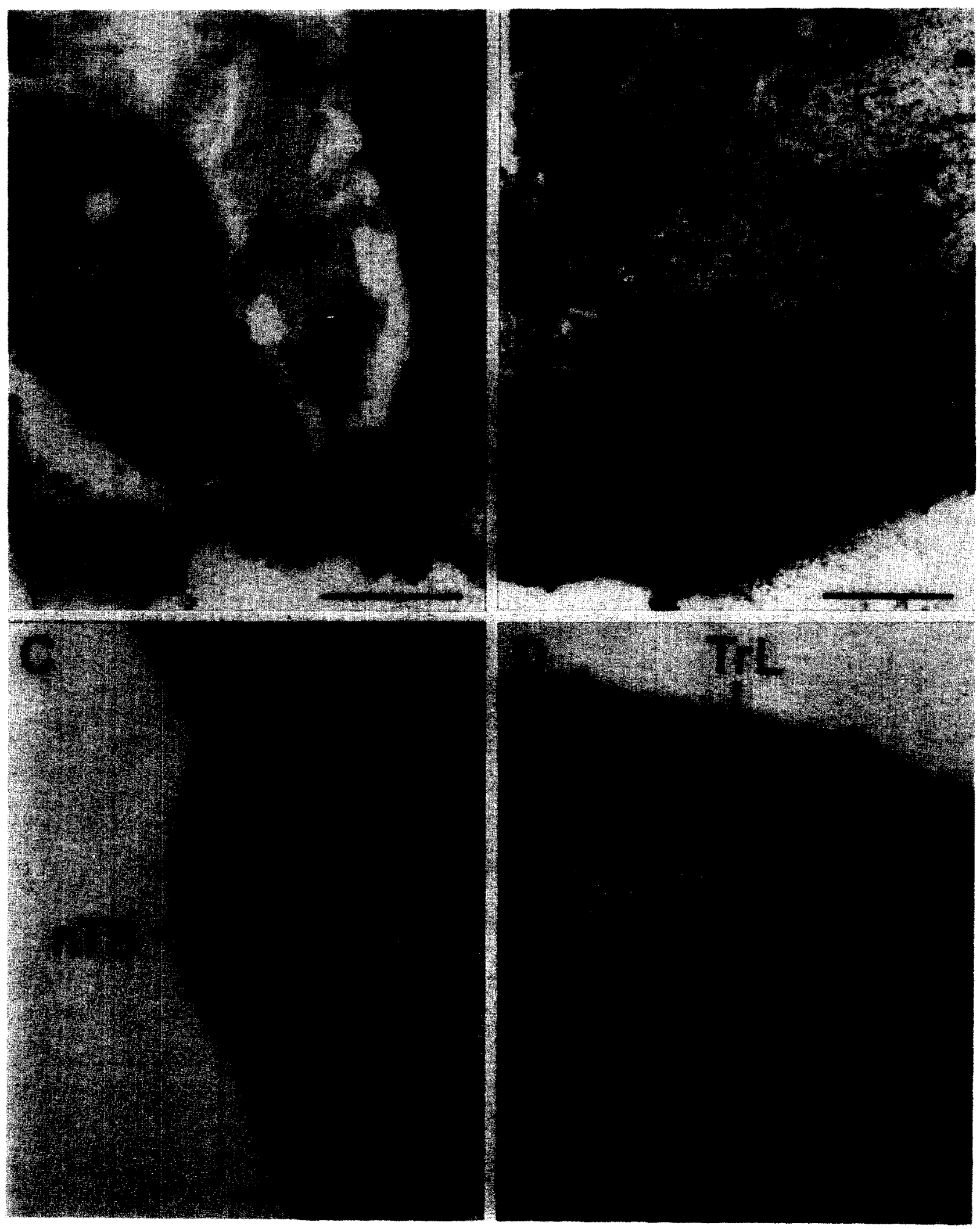


tegmentum. Since this region of the turtle tegmentum is known to contain numerous dopaminergic neurons [12], it seems likely that some of the dopaminergic neurons also contain CCK. In mammals, numerous neurons containing both dopamine and CCK8LI have been found in the ventral tegmental area $[31,32]$. Although the presence in turtles of CCK8LI in the medial tegmental neurons and in fibers of the medial striatum (comparable to the nucleus accumbens of mammals) and olfactory tubercle suggests the existence of a CCK8LI-containing mesolimbic pathway to the basal telencephalon (comparable to that in mammals), it is of interest to note that the levels of CCK8 measured in turtle basal telencephalon by RIA are only $1 / 20-1 / 40$ of those in the mammalian basal telencephalon.

Comparative neuroanatomical studies during the last two decades have considerably revised the understanding of the evolution of the mammalian cerebral cortex by showing that large regions of the avian and reptilian telencephalon (in turtles, including the DVR and the nonolfactory cortex plus the pallial thickening) are histochemically and anatomically comparable to mammalian neocortex $[54,56,57,80]$. In this context, the levels of CCK8LI in cortex and DVR of turtle are of interest. Although moderate levels of CCK8 were measured by RIA in cortex, very little CCK 8 was found in the DVR. The immunochemically detectible CCK8LI present in turtle cortex, however, is contained in a fiber system that appears to originate from the hypothalamus [68]. Further, CCK8LI-containing neurons were rarely observed in either cortex or DVR in turtle. Thus, the cortex and DVR of turtles appear similar to one another in that both contain very little CCKLI of intrinsic origin. In contrast, in mammals CCK8 is found in its highest brain concentration in the cerebral cortex $[8,9]$, in which the bulk of the CCK8 appears to be contained in nonpyramidal local circuit (or intrinsic) neurons of (primarily) neocortical layers II-III [51,59]. The relative scarcity of intrinsic CCK8LI in both the cortex and DVR of turtles is surprising since the telencephalic neocortex of mammals and the cortex and DVR of turtles are similar in terms of many other details of their connections and neurotransmitter-specific cell types $[12,24,37,54,65,67$, 71, 72]. Preliminary immunohistochemical studies (Reiner, unpublished observation) indicate that intrinsic CCK8L.1containing neurons are also rare in the cortex and DVR of caiman (a crocodilian) and in the Wulst (comparable to reptilian cortex) and DVR of pigeons. Although higher levels of a CCK-like substance have been measured by RIA in the telencephalic hemispheres (cortical-equivalent tissue plus basal telencephalon) of birds than in the telencephalic hemispheres of turtles $[30,82]$, the levels in birds are nonetheless much lower than in the cerebral hemispheres of mammals. Further, previous studies in birds have not specifically measured the levels of CCK8 in the telencephalic corticalequivalent tissue (Wulst and DVR); and thus, the concentration of CCK 8 in the Wulst and DVR in birds may be lower than in the telencephalon as a whole. Even lower levels of CCK8 have been found in the dorsal cerebrum of frogs by RIA than in turtle cortex (N. B. The frog telencephalon lacks a DVR but does possess a dorsal pallial region comparable to reptilian cortex) [11,57]. As in turtles, the highest levels of CCK8 in the frog CNS are found in the hypothalamus and neurohypophysis [11]. Thus, although more information is needed on the levels of CCK8 in the telencephalic corticalequivalent regions in birds and nonchelonian reptiles, it seems likely that the telencephalic cortical-equivalent regions of living nonmammalian terrestrial vertebrates largely lack at least one major population of neurons characteristic of mammmalian neocortex, namely intrinsic CCK8containing neurons. These intrinsic $\mathrm{CCK}$-containing cortical neurons may have not become characteristic of the cerebral hemispheres until the evolution of mammalian neocortex.

The observation that a population of neurons that is predominantly restricted to layers II-III within mammalian neocortex is largely absent from cortical-equivalent regions of the reptilian telencephalon raises the question as to whether or not other populations of neurons predomiantly restricted to layers II-III of mammalian neocortex are also absent from or extremely rare in reptilian cortical-equivalent regions. Ebner [24] previously noted that the telencephalic cortex in turtles, although in many respects similar to mammalian neocortex, appears to lack the afferent and efferent connections that uniquely characterize layers I-III of mammalian neocortex. He consequently suggested that turtle cortex in its entire depth may be comparable to layers IV-VI of mammalian neocortex and that neurons in neocortical layers I-III may largely be without correspondent in turtle cortex. The present data indicating that CCK8LI-containing neurons are rare in turtle cortex is consistent with this suggestion. The few CCK8LI-containing neurons observed in turtle cortex and DVR in the present study may be comparable to the few CCK8LI-containing neurons in layers IV-VI of mammalian neocortex. The CCK8LI-containing neurons of layers II-III of mammalian neocortex may not be represented in turtle cortex and DVR. The results of several other immunohistochemical studies are also consistent with Ebner's suggestion. Preliminary results indicate that VIPergic neurons, which are predominantly found in layers II-III of mammalian neocortex [49], are also extremely rare in turtle cortex and DVR [66]. In contrast, peptidergic neurons that are abundant in layers IV-VI of the mammalian neocortex (regardless of whether or not they are also abundant in layers I-III), such as those containing somatostatin, a substance P-like peptide and an APP-like peptide $[3,28,50]$, are abundant in turtle cortex and DVR $[66,68,72,83]$. In order to more fully ascertain the extent of the changes that occurred during the evolution of neocortical layers I-III in the mammalian lineage, further studies are required to determine the extent to which the histochemically-defined and hodologically-defined neuronal cell types predominantly found in layers II-III of the mammalian neocortex are present or absent in living reptiles. Such studies will help determine which of the cell types characteristic of layers I1-1II of mammalian neocortex first appeared in the mammalian lineage and which were already present in the telencephalic cortical-equivalent tissue of the reptilian common ancestors of living mammals and reptiles. It is possible that the neurons predominantly found in layers II-III of mammalian neocortex may largely have been absent in ancestral reptiles and that the early evolution of mammals was characterized by an elaboration and proliferation of the neuronal populations making up layers II-III. The Wulst and DVR of birds, however, clearly possess specific regions that show efferent projections characteristic of layers II-III of mammalian neocortex $[69,74]$. It is possible, however, that neuronal populations with efferent projections similar to those of mammalian cortical layers II-III have evolved independently in birds.

In summary, CCK8 appears to be an evolutionarily stable neuropeptide whose chemical structure has been conserved during the evolution of terrestrial vertebrates. In addition. CCK8 appears to be present in many of the same neural systems of the diencephalon, brainstem and spinal cord in all 
terrestrial vertebrates studied. The concentration (and presumably the role) of CCK8 in these brainstem regions also appears to have been largely conserved. During the evolution of mammals from earlier land vertebrates, however, CCK8 appears to have changed from a substance whose highest brain concentration was within the basal diencephalon to a peptide that has its highest concentration in the cerebral cortex. Although the functional significance of this specific change requires further elucidation, this change may have been one of the many related changes in cerebral hemisphere organization that occurred during the evolution of mammalian neocortex.

\section{ACKNOWLEDGEMENTS}

We wish to gratefully thank Patricia A. Lindaman and Gary Henderson for excellent technical assistance and Theresa Gonzales and John Beckerman for assistance with photography and illustrations. This research was supported by NS-19620 (A.R.), NS-18335 (M.C.B.), NS-18667 (M.C.B.) and a grant from the American Parkinson Disease Association (M.C.B.).

\section{REFERENCES}

1. Acher, R. Evolution of neuropeptides. Trends Neurosci 4: 223-229, 1981.

2. Balaban, C. D. Structure of the anterior dorsal ventricular ridge in turtles (Pseudemys scripta elegans). J Morphol 158: 291-322, 1979.

3. Beach, T. G. and E. G. McGeer. Neocortical substance $P$ neurons in the baboon: An immunohistochemical finding. Neurosci Lett 41: 265-270, 1983.

4. Beinfeld, M. C. An HPLC and RIA analysis of the cholecystokinin peptides in rat brain. Neuropeptides 1: 203-209, 1981

5. Beinfeld, M. C. Chromatographic characterization of gastrin/cholecystokinin peptides in bovine and porcine pituitary. Peptides 3: 531-534, 1982.

6. Beinfeld, M. Cholecystokinin in the central nervous system: A minireview. Neuropeptides 3: 411-427, 1983.

7. Beinfeld, M., R. T. Jensen and M. J. Brownstein. HPLC separation of cholecystokinin peptides, two systems. I Liquid Chromatography 3: 1367-1361, 1980.

8. Beinfeld, M. C., M. E. Lewis, L. E. Eiden, G. Nilaver, C. B. Pert and A. Pert. The distribution of cholecystokinin and vasoactive intestinal peptide in rhesus monkey brain as determined by radioimmunnassay. Neuropeptides 3: 337-344, 1983

9. Beinfeld, M. C., K. K. Meyer, R. L. Eskay, R. T. Jensen and M. J. Brownstein. The distribution of cholecystokinin immunoreactivity in the central nervous system of the rat as determined by radioimmunoassay. Brain Res 212: 51-57, 1981.

10. Beinfeld, M. C. and M. Palkovits. Distribution of cholecystokinin (CCK) in the rat lower brain stem nuclei. Brain Res 238: 260-265, 1982.

11. Beinfeld, M. C., J. R. Trubatch and M. J. Brownstein. Cholecystokinin peptides in the brain and pituitary of the bullfrog Rana catesbiana: Distribution and characterization. Brain Res 268: 192-196, 1983.

12. Brauth, S. E., A. Reiner, C. A. Kitt and H. J. Karten. The substance P-containing striato-tegmental path in reptiles: An immunohistochemical study. J Comp Neurol 219: 305-327, 1983.

13. Buchan, A. M. J., V. Lance and J. M. Polak. Regulatory peptides in the gastrointestinal tract of Alligator mississippiensis. An immunocytochemical study. Cell Tissue Res 231: 439-449, 1983.

14. Carraway, R., S. E. Ruane and H. R. Kim. Distribution and immunochemical character of neurotensin-like material in representative vertebrates and invertebrates: Apparent conservation of the $\mathrm{COOH}$-terminal region during evolution. Peptides 1: $115-123,1982$

15. Cho, H. J., Y. Shiotani, S. Shiosaka, S. Inagaki, Y. Kubota, H. Kiyama, K. Umegaki, K. Tateishi, E. Hashimura, T. Hamaoka and $\mathrm{M}$. Tohyama. Ontogeny of cholecystokinin-8-containing neuron system of the rat: An immunohistochemical analysis. I. Forebrain and upper brainstem. I Comp Neurol 218: 25-41, 1983

16. Coons, A. H. Fluorescent antibody methods. In: General Cytochemical Methods, edited by J. F. Danielli. New York: Academic Press, 1958, pp. 399-422.

17. Desan, P. Connections of cerebral cortex in the turtle (Pseudemys scripta elegans). Soc Neurosci Abstr 7: 85, 1981.
18. Dimaline, R. Is caerulein amphibian CCK? Peptides 4: 457-462, 1983.

19. Dimaline, R., B. B. Rawdon, S. Brando, A. Andrew and J. P. Loveridge. Biologically active gastrin/CCK-related peptides in the stomach of a reptile, Crocodylus niloticus: Identified and characterized by immunochemical methods. Peptides 3: 977984, 1982.

20. Dockray, G. J. The physiology of cholecystokinin in brain and gut. Br Med Bull 38: 253-258, 1982.

21. Dockray, G. J., R. A. Gregory, J. B. Hutchison, J. I. Harris and M. J. Runswick. Isolation, structure and biological activity of two cholecystokinin octapeptides from sheep brain. Nature 274: $711-713,1978$.

22. Dodd, J. and J. S. Kelly. The actions of cholecystokinin and related peptides on pyramidal neurons of the mammalian hippocampus. Brain Res 105: 337-350, 1981.

23. Doer-Schott, J., J.-C. Garaud and R. O. Claus. Immunohistochemical localization of a gastrin-like peptide in the brain of an amphibian, Xenopus laevis daud. Cell Tissue Res 203: 65-78. 1981.

24. Ebner, F. F. The forebrain of reptiles and mammals. In: Evolution of Brain and Behavior in Vertebrates. edited by R. B. Masterton, M. E. Bitterman, C. B. G. Campbell and N. Hotton. New York: John Wiley and Sons, 1976, pp. 147-167.

25. Emson, P. C., C. M. Lee and J. F. Rehfeld. Cholecystokinin octapeptide: Vesicular localization and calcium dependent release from rat brain in vitro. Life Sci 26: 2157-2163, 1980.

26. Engelhardt, R. P., N. Dhainaut-Courtois and G. Tramu. Immunohistochemical demonstration of a CCK-like peptide in the nervous system of a marine annelid worm, Nereis diversicolor O.F. Muller. Cell Tissue Res 227: 401-411, 1982.

27. Eskay, R. L. and M. C. Beinfeld. HPLC and RIA of the cholecystokinin peptides in the vertebrate neural retina. Brain Res 246: 315-318.

28. Finlay, J. C. W., J. L. Maderdrut, L. J. Roger and P. Petrusz. The immunocytochemical localization of somatostatincontaining neurons in the rat central nervous system. Neuroscience 6: 2173-2192, 1981.

29. Frey, P. Cholecystokinin octapeptide (CCK 26-33), nonsulfated octapeptide and tetrapeptide (CCK 30-33) in rat brain: Analysis by high pressure liquid chromatography (HPLC) and radioimmunoassay (RIA). Neurochem Int 5: 811-815, 1983.

30. Goldman, S. A. and B. S. Schneider. The ontogeny of cholecystokinin immunoreactivity in vertebrate brain. Soc Neurosci Abstr 7: 97, 1981.

31. Hokfelt, T., J. F. Rehfeld, L. Skirboll, B. Ivemark, M. Goldstein and M. Markey. Evidence for co-existence of dopamine and CCK in mesolimbic neurons. Nature 285: 476-478, 1980

32. Hokfelt, T., L. Skirboll, J. F. Rehfeld, M. Goldstein, M. Markey and O. Dann. A subpopulation of mesencephalic dopamine neurons projecting to limbic areas contains a cholecystokinin-like peptide: Evidence from immunohistochemistry combined with retrograde tracing. Neuroscience 5: 2093-2124, 1980. 
33. Holmquist, A. L., G. J. Dockray, G. L. Rosenquist and J. H. Walsh. Immunochemical characterization of cholecystokininlike peptides in lamprey gut and brain. Gen Comp Endorrinol 37: 474-481, 1979.

34. Innis, R. B., F. M. A. Correa, G. R. Uhl, B. Schneider and S. Snyder. Cholecystokinin octapeptide-like immunoreactivity: histochemical localization in rat brain. Proc Natl Acad Sci USA 76: 521-525, 1979.

35. Innis, R. B. and S. H. Snyder. Distinct cholecystokinin receptors in brain and pancreas. Proc Natl Acad Sci USA 77: 6917$6921,1980$.

36. Jeftinija, S., V. Miletic and M. Randic. Cholecystokinin octapeptide excites dorsal horn neurons both in vivo and in vitro. Brain Res 213: 231-236.

37. Karten, H. J. The organization of the avian telencephalon and some speculations on the phylogeny of the amniote telencephaIon. Ann NY Acad Sci 167: 164-179, 1969.

38. King, J. A. and R. P. Millar. Structure of chicken hypothalamic luteinizing hormone-releasing hormone. I. Structural determination on partially purified material. $J$ Biol Chem 257: 10722$10728,1982$.

39. King, J. A. and R. P. Millar. Structure of chicken hypothalamic luteinizing hormone-releasing hormone. II. Isolation and characterization. J Biol Chem 257: 10729-10732, 1982.

40. Kubota, Y., S. Inagaki, S. Shiosaka, H. J. Cho, K. Takeishi, E. Hashikawa, T. Hamaoka and M. Tohyama. The distribution of cholecystokinin octapeptide-like structures in the lower brain stem of the rat: An immunohistochemical analysis. Neuroscience 9: 587-604, 1983.

41. Lamour, Y., P. Dutar and A. Jobert. Effects of neuropeptides on rat cortical neurons: Laminar distribution and interaction with effect of acetylcholine. Neuruscience 10: 107-117, 1983.

42. Larsen, B. A. and S. R. Vigna. Gastrin/cholecystokinin-like immunoreactive peptides in the Dungeness crab, Cancer magister (Dana): Immunohistochemical and biological characterization. Regul Pept 7: 155-170, 1983.

43. Larsson, L. I. and J. F. Rehfeld. Evidence for a common evlutionary origin of gastrin and cholcystokinin. Nature London 269: $335-338,1977$.

44. Larsson, L. I. and J. F. Rehfeld. Localization and molecular heterogeneity of cholecystokinin in the central and peripheral nervous system. Brain Res 265: 201-218, 1979.

45. Ljungdahl, A., T. Hokfelt and G. Nilsson. Distribution of substance P-like immunoreactivity in the central nervous system of the rat. I. Cell bodies and nerve terminals. Neuroscience 3: 861-944, 1978.

46. Loren, I., J. Alumets, R. Hakanson and F. Sundler. Distribution of gastrin and CCK-like peptides. Histochemistry 59: 249 $257,1979$.

47. Lowry, O. H., N. J. Rosebrough, A. L. Carr and R. J. Randall. Protein measurement with the Folin phenol reagent. $I$ Biol Chem 193: 265-275, 1951.

48. Maderdrut, J. L., T. L. Yaksh, P. Petrusz and V. L. W. Go. Origin and distribution of cholecystokinin-containing nerve terminals in the lumbar dorsal horn and nucleus caudalis of the cat. Brain Res 243: 363-368, 1982.

49. McDonald, J. K., J. G. Parnavelas, A. N. Karamanlidis and N. Brecha. The morphology and distribution of peptide-containing neurons in the adult and developing visual cortex of the rat. II. Vasoactive intestinal polypeptide. $J$ Neurocytol 11: 825-837, 1982.

50. McDonald, J. K., J. G. Parnavelas, A. N. Karamanlidis and N. Brecha. The morphology and distribution of peptide-containing neurons in the adult and developing cortex of the rat. IV. Avian pancreatic polypeptide. $I$ Neurocytol 11: 985-995, 1982

51. McDonald, J. K., J. G. Parnavelas, A. N. Karamanlidis, G. Rosenquist and N. Brecha. The morphology and distribution of peptide-containing neurons in the adult and developing visual cortex of the rat. III. Cholecystokinin. I Neurocytol 11: 881 $895,1982$.
52. Micevych, P., V. C. W. Go and T. L. Yaksh. Simultaneous measurement of VIP and CCK released from rat and cat cortical slices. Soc Neurosci Abstr 7: 605, 1981.

53. Miller, L. J., I. Jardine, E. Weissman, V. L. W. Go and D. Speicher. Characterization of cholecystokinin from human brain. $J$ Neurochem 43: 835 840, 1984.

54. Nauta, W. J. H. and H. J. Karten. A general profile of the vertebrate brain with sidelights on the ancestry of the cerebral cortex. In: The Neurosciences. Secont Study Program, edited by G. C. Quarton, T. Melnechek and F. O. Schmitt. New York: Rockefeller University Press, 1970. pp. 7-26.

55. Nicoll, R. A., C. Schenker and S. Leeman. Substance $P$ as a transmitter candidate. Annu Rev Neurosci 3: 227-268, 1980.

56. Northcutt, R. G. Forebrain and midbrain organization in lizards and its phylogenetic significance. In: Behavior and Neurology of Lizards, edited by N. Greenberg and P. D. MacLean. Bethesda: NIMH, 1978, pp. 11-64,

57. Northcutt, R. G. Evolution of the telencephalon in nonmammals. Annu Rev Neurosci 4: 301-350, 1981

58. Palkovits, M., J. Z. Kiss, M. C. Beinfeld and T. H. Williams Cholecystokinin in the nucleus of the solitary tract of the rat: Evidence for its vagal origin. Brain Res 252: 386-390, 1982.

59. Peters, A., M. Miller and L. M. Kimerer. Cholecystokinin-like immunoreactive neurons in rat cerebral cortex. Neurostienc' 8: $431-448,1983$.

60. Phillis, J. W. and J. R. Kirkpatrick. The actions of motilin luteinizing hormone-releasing hormone, cholecystokinin, somatostatin, vasoactive intestinal peptide and other peptides on rat cerebral cortical neurons. Can J Physiol pharmacol 58: $612-623,1980$.

61. Pinget, M., E. Straus and R. S. Yalow. Localization of cholecystokinin-like immunoreactivity in isolated nerve terminals. Proc Natl Acad Sci USA 75: 6324-6326, 1978

62. Pinget, M., E. Straus and R. S. Yalow. Release of cholecystokinin from a synaptosome-enriched fraction of rat cerebral cortex. Life Sci 25: 339-342, 1979.

63. Powers, A. S. and A. Reiner. A stereotaxic atlas of the forebrain and midbrain of the eastern painted turtle (Chrvsemys picta pista). J Hirnforschung 21: 125-159, 1980.

64. Rehfeld, J. F., N. Gotterman, L. I. Larsson, P. C. Emson and C. M. Lee, Gastrin and cholecystokinin in the central and peripheral neurons. Fed Proc 38: 2325-2329, 1979.

65. Reiner, A. Comparative studies of opioid peptides: enkephalin distribution in turtle central nervous system. Soc Neurosci Abstr 9: 439, 1983.

66. Reiner, A. Neuropeptides in the reptilian nervous system. In: Biology of Reptilia. edited by C. Gans and R. G. Northcutt. New York: Academic Press, in press.

67. Reiner, A., S. E. Brauth and H. J. Karten. Evolution of the amniote basal ganglia. Trends Neurosci 7: 320-325, 1984.

68. Reiner, A., W. D. Eldred, M. C. Beinfeld and J. E. Krause. The co-occurrence of a substance P-like peptide and cholecystokinin- 8 in a fiber system of turtle cortex. $J$ Nelorosc $i$ 5: $1527-1544,1985$.

69. Reiner, A. and H. J. Karten. The laminar source of efferent projections from the avian Wulst. Brain Res 275: 349-354, 1983.

70. Reiner, A.. H. J. Karten and N. C. Brecha. Enkephalinmediated basal ganglia influences over the optic tectum: Immunohistochemistry of the tectum and the lateral spiriform nucleus in pigeons. I Comp Neurol 208: 37-53, 1982.

71. Reiner, A., H. J. Karten and A. R. Solina. Substance P: Lo calization within paleostriatal-tegmental pathways in the pigeon. Neuroscience 9: 61-85, 1983.

72. Reiner, A., J. E. Krause, K. T. Keyser, W. D. Eldred and J. F. McKelvy. The distribution of substance $P$ in the turtle nervous system: A radioimmunoassay and immunohistochemical study. I Comp Neurol 226: 50-75, 1984.

73. Riss, W., M. Halpern and F. Scalia. The quest for clues to forebrain evolution - the study of reptiles. Brain Behav Evol 2: $1-50,1969$. 
74. Ritchie, T. C. and D. H. Cohen. The avian tectofugal visual pathway: Projections of its telencephalic target, the ectostriatal complex. Soc Neurosci Abstr 3: 94, 1977.

75. Rogawski, M. A. Cholecystokinin octapeptide: Effects on the excitability of cultured spinal neurons. Peptides 3: 545-551, 1982.

76. Rostene, W. H., C. Leranth, M. Maletti, E. Mezey, J. Besson, L. E. Eiden, G. Rosselin and M. Palkovits. Distribution of vasoactive intestinal peptide (VIP) following various brain transections in the rat by radioimmunoassay and electron microscopic immunocytochemistry. Neuropeptides 2: 337-350, 1982.

77. Saito, A., H. Sankaran, I. D. Goldfine and J, A. Williams. Cholecystokinin receptors in the brain: Characterization and distribution. Science 208: 1155-1156, 1980.

78. Sternberger, L. Immunocytochemistry, second edition. New York: John Wiley and Sons, 1979.

79. Strause, E., S. Ryder. J. Eng and R. S. Yalow. Nature of immunoreactive CCK in rat and pig brain. Peptides 2: Suppl 2, 89-92, 1981 .
80. Ulinski, P. S. Dorsal Ventriclar Ridge: A Treatise on Forebrain Organization in Reptiles and Birds. New York: John Wiley and Sons, 1983.

81. Vanderhaeghen, J. J., F, Lotstra, J. DeMey and C. Gilles. Immunohistochemical localization of cholecystokinin and gastrin-like peptides in the brain and hypophysis of the rat. Proc Natl Acad Sci USA 77: 1184-1190, 1980.

82. Vanderhaeghen, J. J., J. C. Signeau and W. Gepts. New Peptide in the vertebrate CNS reacting with antigastrin antibodies. $\mathrm{Na}$ ture 257: 604-605, 1975.

83. Weind, A., J. Teipel and G. Kuchling. Somatostatin in the brain of the turtle Testudo Hermanni Gmelin. An immunohistochemical study. Peptides 5: 91-100, 1984.

84. Weller, T. H. and A. H. Coons. Fluorescent antibody studies with agents of varicella and herpes zoster propagated in vitro. Proc Soc Exp Biol Med 86: 789-794, 1954.

85. Yamada, T., N. Brecha, G. Rosenquist and S. Basinger. Cholecystokinin-like immunoreactivity in frog retina: Localization, characterization, and biosynthesis. Peptides 2: 93-97, 1981. 